\title{
Influence of pre-fermentative addition of aqueous solution tannins extracted from oak wood (Quercus petraea) on the composition of Grillo wines
}

\author{
Onofrio Corona ${ }^{1}$ (]) Paola Bambina ${ }^{1} \cdot$ Diego De Filippi $^{2} \cdot$ Luciano Cinquanta $^{1}$
}

Received: 23 September 2020 / Revised: 30 November 2020 / Accepted: 12 December 2020 / Published online: 19 May 2021

(c) The Author(s) 2021

\begin{abstract}
In this research, the chemical characterization of fixed and volatile compounds of two different tannins in aqueous solution (Pratiko® L-Harvest and L-Fruit) extracted from oak wood, has been studied. The influence of the above tannins, at different concentrations, on the alcoholic fermentation kinetics and on the composition and sensorial characteristics of a white wine were then evaluated. The wines added tannins in aqueous solution compared to control wines showed significant differences in fixed compounds (colloids, polyphenols and ellagitannins) and volatile compounds (phenolic aldehydes, volatile phenols, furanic and piranic compounds). The differences of aqueous solution tannins extracted from oak wood were partly due to the drying/maturing and roasting methods used in barrel production. Alcoholic fermentation was partially facilitated by the addition of tannins in aqueous solution. The wines obtained showed a higher content of ethyl esters of medium-chain fatty acids (from 22 to $31 \%$ ) and, in some cases, higher acetate alcohols (from 15 to 28\%), relevant to the olfactory sensations provided to the wines. The tannins added to the must before fermentation also made it possible to obtain an additional supply of polyphenols (from 25 to $85 \%$ ) able to induce more complex sensory profiles in the wines, with increased persistent taste notes.
\end{abstract}

Keywords White wine $\cdot$ Aqueous solution tannins of oak wood $\cdot$ Phenolic compounds · Aroma compounds · Sensory analyses

\section{Introduction}

Oenological tannins are complex polyphenolic compounds synthesised from a wide range of plant species organs [1], including chestnut, oak and exotic wood, grape skin and seeds and pathogen-induced galls. The Codex Alimentarius Commission [2] classified commercial tannins as food additive No. 181, which may act as processing aids [3], as tannins are also used to facilitate the fining of both must and wine and their use is regulated and authorized by the International Oenological Code (OIV) [4]. Commercial oenological tannins are extracted from a single botanical species or mixtures of several species and can range in colour from pale-yellow to reddish brown. Based on their

Onofrio Corona

onofrio.corona@unipa.it

1 Department of Agricultural, Food and Forest Sciences, University of Palermo, 90128 Palermo, Italy

2 HTS Enologia, Marsala, 91025 Trapani, Italy structure, tannins are conventionally divided into condensed and hydrolysable tannins [5-10].

Condensed tannins, also called proanthocyanidins (with reference to the red colour that develops after treatment with diluted acid), are a group of important secondary metabolites [11], deriving from the oligomerization and polymerization of monomeric units of polyhydroxyl flavan-3-ol, bound by C4-C8 and C4-C6 acid-labels (type B proanthocyanidins) $[12,13]$, or by an additional C2-O-C7 or C2-O-C5 (type A proanthocyanidins) bond $[14,15]$.

Grape skin tannins are composed of procyanidins and prodelphinidins (since their acidic cleavage gives cyanidin and delphinidin) with high degree of polymerization (DP) and low level of galloylation, whereas grape-seed tannins are composed only of procyanidins, with a lower DP and a higher level of galloylation [10].

Hydrolysable tannins are heterosidic phenolic compounds, deriving from esterification between $\beta$-Dglucopyranose hydroxyl groups with either gallic acid or hexahydroxydiphenic acid $[8,16,17]$. Based on their acid 
hydrolysis products, hydrolysable tannins are classified in gallotannins and ellagitannins [8].

The chemical composition of tannin extracts is influenced by several factors, including botanical origin [18], extraction protocol [19], and the presence of interfering compounds [20]. A wide range of commercial oenological tannins is available on the market, mainly hydrolysable, condensates or mixtures of the two types, both in solid state (wood chips) and in aqueous solution. Tannins in aqueous solution represent a valid alternative to wood chips, due to the ease of use and solubilization in musts and wines, as well as the possibility to provide, depending on the techniques of preparation of the liquid extract, other constituents in addition to tannin molecules, such as volatile compounds and polysaccharides [21-24].

Since commercial tannins have different formulations and chemical compositions, they are also used for purposes other than ageing must and wine. These properties can be classified into different groups, including "impact on oxygen/metals", "impact on color/pigments", "protein interaction", "sensory/sensory properties" and "bacteriostatic effects" [25]. Several studies have reported that hydroalcoholic extracts from oak wood contain aromatic acids, such as ferulic acid, vanillic acid, or synapinic acid, coumarins, such as scopoletin and umbelliferone, lignols, such as lioniresinol, gallic acid as well as hydrolysable tannins, such as castalagina and vescalagina [26].

Given the wide range of commercial tannins on the market and their great chemical diversity, the main objective of this research was to characterize the fixed and volatile compounds of two types of tannins in aqueous solution extracted from oak wood. Furthermore, their influence on the kinetics of alcoholic fermentation and on the composition and sensorial characteristics of a white wine, was evaluated.

\section{Materials and methods}

\section{Analysis of aqueous solution tannins}

\section{Physicochemical analysis}

The tannins were extracted from oak woods (Quercus petraea) with two different toasting degrees. Pratiko ${ }^{\circledR}$ L-Harvest (I-Oak S.r.l., Brescia, Italy) (H trials), derived from not toasted oak wood, whereas Pratiko ${ }^{\circledR}$ L-Fruit (I-Oak S.r.1., Brescia, Italy) (F trials), derived from slightly toasted oak wood. The chemical composition of the two preparations of aqueous solution tannins was assessed according to OIV [27], including density, $\mathrm{pH}$, total and volatile acidity determinations. Total colloids were investigated by alcohol-precipitable using $80 \%$ of ethanol solution acidified with $\mathrm{HCl}: \mathrm{H}_{2} \mathrm{O}$ 1:1 [28].

\section{Determination of phenolic compounds}

The phenolic compounds present in aqueous solution tannins, $\mathrm{H}$ and $\mathrm{F}$ trials, $(5 \mathrm{~mL})$ were extracted in triplicate with methanol/water $(4: 1,3 \times 10 \mathrm{~mL})$ according to Scalbert et al. [29]. The methanol was removed under reduced pressure; the aqueous solution was acidified by $6 \mathrm{~N}$ hydrochloric acid $(\mathrm{pH} 2 \pm 0.5)$ and extracted by freshly distilled diethyl ether $(3 \times 5 \mathrm{~mL})$. Low-molecular-weight phenols like $(+)$-catechin (which would interfere with proanthocyanidins in their determination by reaction with vanillin) and ellagic acid (nearly insoluble in aqueous solutions) were thus separated from tannins. After the mixtures were dried with sodium sulfate, diethyl ether was removed and the ether-soluble material was dissolved in $1 \mathrm{~mL}$ of methanol. The volume of the residual aqueous solution was made to $10 \mathrm{~mL}$.

Total phenols were determined by the reduction of phosphotungstic-phosphomolybdic acid (Folin-Ciocalteu's reagent) to blue pigments, in alkaline solution according to Singleton et al. [30]. The extract was diluted 5-10 times by methanol (ether extracts) or water (aqueous extracts) to obtain a final absorbance below 1 .

Proanthocyanidins were quantified as described by Bate-Smith [31]. In two separate test tubes (reaction tube and blank tube), $2 \mathrm{~mL}$ of wine sample, $10.5 \mathrm{~mL}$ of ethanol and $12.5 \mathrm{~mL}$ of hydrochloric acid $37 \%(\mathrm{v} / \mathrm{v})$ containing $300 \mathrm{mg} / \mathrm{L}$ of $\mathrm{FeSO}_{4} .7 \mathrm{H}_{2} \mathrm{O}$ were added. The reaction tube was heated in a water bath at $100{ }^{\circ} \mathrm{C}$ for $50 \mathrm{~min}$, while the blank tube was left to stand in the dark in ice. After the reaction, the reaction tubes were cooled down in ice for $10 \mathrm{~min}$ and the absorbance was recorded at $550 \mathrm{~nm}$. The concentration of proanthocyanidins was calculated by multiplying the difference in absorbance between the reaction tube and the blank tube by the factor 1162.5 to express the result as $\mathrm{mg}$ cyanidin/L [32]. Flavan-3-ols were determined according to Di Stefano et al. [32] by UV-Vis spectrophotometry (Beckman DU 640 spectrophotometer, Milan, Italy) using vanillin assays in ether extracts or aqueous extracts. Ellagitannins were determined by oxidation with nitrous acid according to Bate-Smith [33]. In a tube sealed with a Teflon-lined screw cap, $0.2 \mathrm{~mL}$ of aqueous extract was added to $1.8 \mathrm{~mL}$ of $1: 1$ methanol/water and $0.16 \mathrm{~mL}$ of aqueous $6 \%$ acetic acid. Nitrogen was bubbled for $5-10 \mathrm{~min}$ and $0.16 \mathrm{~mL}$ of an aqueous solution of $6 \%$ sodium nitrite was added. Nitrogen was bubbled during a few more seconds, and the tube was sealed and kept $100 \mathrm{~min}$ in a water bath at $25^{\circ} \mathrm{C}$. The absorbance was read at the maximum at $590 \mathrm{~nm}$. Results are expressed as 4,6-hexahydroxydiphenoyl-glucose (Fluka) per liter.

The phenolic compounds were determined by UV-Vis spectrophotometry (Beckman DU 640 spectrophotometer, Milan, Italy). 


\section{Volatile profiles}

Oak volatile compounds were obtained by direct dichloromethane extraction, according to Cutzach et al. [22]. In brief, the samples of aqueous solution tannins $(25 \mathrm{~mL})$ were directly extracted by dichloromethane $(25 \mathrm{~mL})$ for $24 \mathrm{~h}$ at $20{ }^{\circ} \mathrm{C}$ with $700 \mathrm{rpm}$ magnetic agitation. The organic phase thus obtained was concentrate through a $1 \mathrm{~g} \mathrm{C} 18$ cartridge (Isolute, SPE Columns, Uppsala, Sweden, part n 221-0100C), according to the method reported by Corona [34] therefore, dried on anhydrous sodium sulfate, cold-concentrated with nitrogen gas to $2 \mathrm{~mL}$. The extract $(1 \mu \mathrm{L})$ was analysed by gas chromatography-FID and gas chromatography-MS in the same way as volatile organic compounds of wines (more detailed information about the analysis is described in Volatile profiles of wines).

\section{Wine-making process}

Vitis vinifera L. cv Grillo grapes were hand-harvested and transported to the cellar. Grillo is a white indigenous variety of the western Sicily, mainly used in the past to produce Marsala wines and now used for quality white wine production [35]. The grapes were then pressed with a pneumatic press using a low-pressure gradient (from 0 to max 1 bar), after destemming and crushing. When the must was obtained, $\mathrm{SO}_{2}(50 \mathrm{mg} / \mathrm{L})$ and pectolytic enzymes $(3 \mathrm{~mL} / 100$ L of Hzym ${ }^{\circledR}$ Clarification Ultra L, HTS enologia, Marsala, Italy) were added. Then, the juice was clarified using a rotary drum vacuum filter. The clear must was stored into seven $500 \mathrm{~L}$ stainless steel tanks.

Diammonium phosphate (DAP) containing thiamine $(0.25 \%)$ (Hnutrix ${ }^{\circledR}$ Dhizote F, HTS enologia, Marsala, Italy) and $\mathrm{SO}_{2}$ were added to obtain $200 \mathrm{mg} / \mathrm{L}$ assimilable nitrogen and $50 \mathrm{mg} / \mathrm{L}$ total $\mathrm{SO}_{2}$, respectively. The must was fermented by inoculation of $20 \mathrm{~g} / 100 \mathrm{~L}$ Saccharomyces cerevisiae (Safoeno BC S103, Fermentis, Marcq-en-Barœul, France) pie de cuvè, in full fermentative activity, with a concentration corresponding to $10 \%$ of the total mass.

Seven experiments, one control wine and six trials were carried out, during which the two different preparations of water solution tannins, were used at three concentration (30, 45 e $60 \mathrm{~mL} / 100 \mathrm{~L}$ ), for each preparation, obtaining the following samples: H30, H45, H60 e F30, F45 e F60.

During fermentation process, conducted at low temperature $\left(15{ }^{\circ} \mathrm{C}\right)$, organic nitrogen, by means of total autolyzed yeast extract (B-energia ${ }^{\circledR}$, HTS enologia, Marsala, Italy) and inorganic nitrogen (Hnutrix ${ }^{\circledR}$ Dhizote F, HTS enologia, Marsala, Italy) were added.

First, nitrogen addition $\left(10 \mathrm{~g} / 100 \mathrm{~L}\right.$ Hnutrix ${ }^{\circledR}$ Dhizote F and $5 \mathrm{~g} / 100 \mathrm{~L} \mathrm{~B}$-energia ${ }^{\circledR}$ ) was performed on the second day of fermentation, when the amount of alcohol reached 1-2\% vol, after two-third of the must volume was pumped over in air. Second, nitrogen addition $\left(5 \mathrm{~g} / 100 \mathrm{~L}\right.$ of Hnutrix ${ }^{\circledR}$ Dhizote $\mathrm{F}$ and $10 \mathrm{~g} / 100 \mathrm{~L}$ of $\mathrm{B}$-energia ${ }^{\circledR}$ ) was performed in the middle of the fermentation process, after one-third of the must volume was pumped over in air. Further nitrogen (3-5 g/100 L B-energia $\left.{ }^{\circledR}\right)$ and oxygen (one-third of the volume of the fermenting must) additions were carried out, when the amount of alcohol reached 8-9\% vol and when fermentation activity was slowed down [36].

The wine obtained was added of $45 \mathrm{~g} / 100 \mathrm{~L}$ bentonite Hclar® Bent Gold (HTS enologia, Marsala, Italy) to achieve protein stabilization, and of $30 \mathrm{~g} / 100 \mathrm{~L}$ PVPP (Hclar ${ }^{\circledR}$ PVPP, HTS enologia, Marsala, Italy) to lowering the flavans content. Tartrate stabilization of wine was obtained by cold stabilization $\left(0{ }^{\circ} \mathrm{C}\right.$ for 20 days $)$. Lastly, a polishing paperboard filtration ( $1 \mu \mathrm{m}$ diameter) was conducted and $\mathrm{SO}_{2}$ was added, to obtain $35-40 \mathrm{mg} / \mathrm{L}$ free $\mathrm{SO}_{2}$ before bottling.

\section{Analysis of wines}

\section{Physicochemical analysis and phenolic compounds}

The analytical determinations of both musts and wines physicochemical parameters, including $\mathrm{pH}$, total and volatile acidity, free and total $\mathrm{SO}_{2}$ and alcohol content, were performed according to the OIV [27]. The reactivity of total polyphenols and flavan-3-ols to p-dimethylaminocinnamaldehyde (p-DAC assay) [32] and acetaldehyde content [37] were determined by UV-Vis spectrophotometry (Beckman DU 640 spectrophotometer, Milan, Italy). Hydroxycinnamoyl tartaric acids (HCTA) were investigated through HPLC (Agilent series 1200 instrument, Milan, Italy), equipped with a C18 column (EconosphereTM C18, $5 \mu \mathrm{m}, 250 \times 4.6 \mathrm{~mm}$ i.d., Lokeren, Belgium, part n ${ }^{\circ} 70,066$ ), injected volume $20 \mu \mathrm{L}$, flow rate $0.6 \mathrm{~mL} / \mathrm{min}$., detection at $210 \mathrm{~nm}$, as reported by Corona [35]. Phenolic compounds were identified and quantified by comparing the retention times of the unknown compound and pure standard, when available, using a diode array detector with the same chromatographic conditions. Caffeoyl tartaric acid and coumaroyl tartaric acid were isolated according to the method described by Singleton et al. [38].

\section{Volatile profiles of wines}

Volatile organic compounds of wine were determined according to the method reported by Corona [34]. In brief, $25 \mathrm{~mL}$ of wine, charged with 1-heptanol as internal standard $(0.25 \mathrm{~mL}$ of $40 \mathrm{mg} / \mathrm{L}$ hydroalcoholic solution), diluted to $75 \mathrm{~mL}$ with distilled $\mathrm{H}_{2} \mathrm{O}$, was passed through a $1 \mathrm{~g} \mathrm{C} 18$ cartridge (Isolute, SPE Columns, Uppsala, Sweden, part $\left.\mathrm{n}^{\circ} 221-0100-\mathrm{C}\right)$ previously activated with $3 \mathrm{~mL}$ of methanol followed by $4 \mathrm{~mL}$ of distilled $\mathrm{H}_{2} \mathrm{O}$. After washing with $30 \mathrm{~mL}$ of distilled $\mathrm{H}_{2} \mathrm{O}$, volatiles were recovered by elution 
with $12 \mathrm{~mL}$ dichloromethane, dehydrated and evaporated to $0.5 \mathrm{~mL}$ prior to injection into the gas chromatographyFID (PerkinElmer Autosystem XL, Milan, Italy) and gas chromatography-MS (Agilent 6890 Series GC system, Agilent 5973 Net Work Mass Selective Detector, Milan, Italy), both equipped with a DB-WAX column (Agilent Technologies, $30 \mathrm{~m}, 0.250 \mathrm{~mm}$ i.d., film thickness $0.25 \mu \mathrm{m}$, part $\mathrm{n}^{\circ}$ 122-7032). Oven temperatures were: $40^{\circ} \mathrm{C}$ for $2 \mathrm{~min}$ (during splitless injection), from 40 to $60{ }^{\circ} \mathrm{C}, 40{ }^{\circ} \mathrm{C} / \mathrm{min}, 60^{\circ} \mathrm{C}$ for $2 \mathrm{~min}$, from 60 to $190{ }^{\circ} \mathrm{C}, 2^{\circ} \mathrm{C} / \mathrm{min}$, from 190 to 230 , $5{ }^{\circ} \mathrm{C} / \mathrm{min}, 230{ }^{\circ} \mathrm{C}$ for $15 \mathrm{~min}$; injector $250{ }^{\circ} \mathrm{C}$, Fid $250{ }^{\circ} \mathrm{C}$, transfer line $230^{\circ} \mathrm{C}$, carrier helium $1 \mathrm{~mL} / \mathrm{min}$.; EM. $70 \mathrm{eV}$. Volatile organic compounds were identified by comparison of the mass spectra and GC retention times with those of the pure commercial standard compounds and by comparing their mass spectra with those within the NIST/EPA/NIH Mass Spectral Library database (Version 2.0d, build 2005). For volatile organic compounds without the commercially available standard, their identification was conducted by matching their mass spectrum with those of the NIST library or reported in literature. The concentration $(\mu \mathrm{g} / \mathrm{L})$ of volatile compounds was determined as 1-heptanol equivalents.

Methanol, ethyl acetate and higher alcohols (propan-1-ol, 2-methyl-butan-1-ol and isoamyl alcohols) were determined on the alcoholic distillate of the wine by gas chromatography with flame ionization detector (FID) detector (PerkinElmer Autosystem XL), as described by Corona et al. [34]. Samples were tested in triplicate for all chemical and physical parameters determinations.

\section{Sensory analyses}

The wines were subjected to sensory analysis, through a trained panel of 24 judges (14 men and 10 women, aged 25-48). For the evaluation of wines sensory profiles, discrimination tests were performed, including two qualitative tests, namely duo-trio test and preference test, and a qualitative-quantitative test, namely sorting test. First two tests were performed comparing the control wine with each trial with different dosages of water solution tannins (trials H30, H45, H60 o F30, F45, F60).

Amber-colored glasses were used to evaluate samples mainly from the olfactory and gustatory point of view, without the influence of wine colour differences.

Finally, in the sorting test, panellists have been asked to sort the samples (control wine and each trials with different dosages of water solution tannins) based on similar perceived sensory characteristics, using visual (colour intensity), olfactory (fruity intensity) and gustatory (complexity and gustatory persistence) descriptors and the preference (both olfactory and gustatory).

\section{Statistical analyses}

Statistical analyses were performed using the statistical software package SPSS (version 13.0; SPSS Inc., Chicago, IL, USA). To compare the mean values of aqueous solution tannins analysed compounds, the Student's Independent Samples $t$ test was performed. Wines data analyses were processed through multivariate analysis of variance (ANOVA). To establish statistical differences by one-way analysis of variance (ANOVA), the Tukey b test for $p \leq 0.05,0.01 \mathrm{e}$ 0.001 was used.

Sensory analysis data of duo-trio tests and preference test were evaluated according to Roessler et al. [39] and Quade test and multiple comparisons, respectively. Significant differences were evaluated with $p \leq 0.05,0.01$ and 0.001 .

\section{Results and discussion}

\section{Composition of water solution tannins: L-Harvest e L-Fruit}

L-Harvest and L-Fruit preparations showed similar $\mathrm{pH}$ values (3.0), some differences were found in density values (1.0788 and 1.0522), in volatile acidity (11.0 and $13.0 \mathrm{meq} / \mathrm{L})$, respectively. Significant differences $(p<0.001)$ in total acidity (199 e $125 \mathrm{meq} / \mathrm{L})$ and colloids content $(7.3 \mathrm{e}$ $5.7 \mathrm{~g} / \mathrm{L}$, respectively) (Table 1) were also found. L-Harvest was richer in water extractable polyphenols than L-Fruit (83 and $61 \mathrm{~g} / \mathrm{L}$, respectively), particularly in ellagitannins (53 and $30 \mathrm{~g} / \mathrm{L})(p<0.01$ e $p<0.001$, respectively). Similar values in ether extractable polyphenols were also found $(2.1$ and $2.0 \mathrm{~g} / \mathrm{L})$. Proanthocyanidins and vanillin reactive flavanols were not detected in either L-Harvest or L-Fruit. Colloids, determined by precipitation with acidified alcohol, were attributed to polysaccharides extracted from wood, in particular hemicellulose and cellulose.

Heat treatment of wood reduces the absolute content of hemicellulosic saccharides (xylose, galactose, arabinose, mannose) [40]. The deterioration of hemicellulose already starts below $180^{\circ} \mathrm{C}$ and galactose, arabinose and mannose are almost completely degraded at $200^{\circ} \mathrm{C}$ [40]. This results from wood degradation that starts with deacetylation of hemicellulose and is followed by de-polymerization of polysaccharides [41]. Because of heat treatment, acetic acid is released from the hemicelluloses of the wood [40].

L-Harvest and L-Fruit, contained several volatile compounds (Table 2), partly already present as free form in oak wood [42], partly resulting from the drying/maturing and toasting methods used in barrel production [42-44]. Among the volatile compounds detected are mainly lactones, acids, phenolic, furanic and piranic aldehydes [45, 46]. Phenolic aldehydes and ring vanillic compounds were 
Table 1 Chemical-physical parameters and phenolic compounds of tannins in aqueous solution

\begin{tabular}{llll}
\hline & L-Harvest & L-Fruit & Sign \\
\hline Density $20{ }^{\circ} \mathrm{C}$ & $1.0788 \pm 0.00$ & $1.0522 \pm 0.00$ & - \\
$\mathrm{pH}$ & $3.04 \pm 0.01$ & $3.02 \pm 0.01$ & - \\
Total acidity (meq/L) & $199.10 \pm 5.11$ & $124.80 \pm 4.82$ & $* * *$ \\
Volatile acidity (meq/L) & $11.00 \pm 0.92$ & $13.00 \pm 0.96$ & - \\
Colloids g/L & $7.33 \pm 0.22$ & $5.71 \pm 0.13$ & $* * *$ \\
Phenolic compounds & & & \\
$\begin{array}{l}\text { Extraction with water } \\
\text { Total phenol (g/L (+)-catechin) }\end{array}$ & $82.7 \pm 11.2$ & $61.0 \pm 8.23$ & $* *$ \\
$\begin{array}{l}\text { Proanthocyanidins (g/L cya- } \\
\quad \text { nidin) }\end{array}$ & n.d. & n.d. & - \\
$\begin{array}{l}\text { Flavan-3-ol by vanillin assays } \\
\quad \text { g/L (+)-catechin) }\end{array}$ & n.d. & n.d. & - \\
$\begin{array}{l}\text { Ellagitannin (g/L) } \\
\text { Extraction with ether }\end{array}$ & $52.64 \pm 4.01$ & $29.93 \pm 2.54$ & $* * *$ \\
Total phenol (g/L (+)-catechin) & $2.11 \pm 0.82$ & $2.01 \pm 0.74$ & - \\
\hline
\end{tabular}

n.d. not detected

Data are expressed as average \pm standard deviation $(n=3)$; Significant differences are indicated by $* *$ and $* * *$ at $p \leq 0.01$ and 0.001 , respectively (Student's Independent Samples $t$ test)

in high concentrations: ethyl vanillate and syringaldehyde were found mainly in L-Harvest $(p<0.001)$, while coniferilic and vanillic aldehydes and acetovanillone, responsible for the vanilla olfactory note, were found mainly in L-Fruit $(p<0.001)$. Volatile phenols, i.e. dihydroeugenol, eugenol, isoeugenol and guaiacol, produced by lignin degradation [23], were found in slightly higher amounts in L-Harvest.

Furanic and piranic volatile compounds are produced by the pyrolysis of polysaccharides (furanic aldehydes) or by carbohydrate transformation in the presence of amino acids through the Maillard reaction (furanones and pyranones) [23], giving rise to several molecules, including furfural acetyl, 3,4-dimetil-2(5H)-furanone, furil-idrossimetilketone, furaneol, furfural 5-methyl, maltol, furfuryl alcohol, which provide woody and smoke notes [47]. These compounds were significantly higher in L-Fruit than L-Harvest. Both cis- and trans-isomers of $\beta$-metil- $\gamma$-octalattone (the so-called oak lactones), responsible for "coconut" olfactory notes [48] were mainly present in L-Fruit $(p<0.05$ e $p<0.01$, respectively). The occurrence of I, II e III 3,4 dihydro 3-oxo- $\alpha$-ionolo isomers, responsible for "tobacco" aroma of oak wood and characterized by high perception threshold [49] confirms that oak wood contains even norisoprenoids, deriving from carotenoids oxidative degradation catalysed by light [50]. Their content was higher in L-Harvest $(p<0.01)$.

\section{Alcoholic fermentation of musts and physicochemical composition of wines}

The clear must, obtained by Grillo grapes, showed 21.7 Brix degrees, $\mathrm{pH}=3.10$ and total acidity $=7.0 \mathrm{~g} / \mathrm{L}$. As can be deduced from Fig. 1, the fermentation kinetics was regular in all trials. Brix degrees and alcohol content evolution (Fig. 1) were subjected to an acceleration after every nitrogen addition and partial open racking of must. Fermentation kinetics was slightly facilitated in control sample and in trials with 30 and $45 \mathrm{~g} / 100 \mathrm{~L}$ of L-Harvest aqueous solution tannins. The addition of tannins after the inoculation of the yeasts had slightly increased the delay phase of the yeasts, particularly in the tests added with $60 \mathrm{~g} / 100 \mathrm{~L}$ of tannins, but without interrupting their activity. In fact, the alcoholic fermentation was completed in 10 days in all trials. The trials showed not significant differences in alcohol content if compared to control wine and quite similar pH values (nearly 3.05). Total acidity, volatile acidity, acetaldehyde, total polyphenols and $p$ - DAC reactive flavanols, were higher in all trials with water solution tannins, with significant $(p<0.05)$ differences (Table 3). Physico-chemical parameters and polyphenolic content showed that yeast activity was favoured by the addition of tannins in aqueous solution, as was the content of un-salified acids (total acidity). The higher total acidity found in tests with both tannins $(p<0.05)$ can be partly explained by the inhibitory action on tartaric precipitation by fixed compounds extracted from oak wood (mainly polysaccharides and polyphenols). These compounds can help to increase the amount of protective colloids in wines, resulting in a decrease in the temperature of spontaneous crystallization and a reduction in tartaric precipitation during cold stabilization of wines [51,52].

The higher volatile acidity found in tests with tannins may depend on the acetic acid formed after degradation of wood hemicellulose [40]. The high acetaldehyde content, on the other hand, is related to the length of the growth and fermentation phases [53]. In particular, early production of acetaldehyde occurs when there is an increase in the duration of the yeast delay phase. The changes that occur during the delay phase are characterized by a global change in protein synthesis caused by the regulation of gene expression. The exposure of yeast cells to a new enriched environment leads to an immediate response through the change of a number of biochemical pathways [54]. The determination of polyphenols in both tannin preparations showed different concentrations of the same (Table 1). The higher content of $p$-DAC reactive flavanols in trials suggested that the oak tannins supplementation enhances the polymerization of flavanol units [55]. Hydroxycinnamyl tartaric acid esters were found in small amounts (but with large differences) in all tests (Fig. 2). GRP (Grape Reaction Product or 2-S-glutathionylcaffeiltartaric acid) was the most representative compound 
Table 2 Volatile organic compounds determined in the tannins in aqueous solution $(\mu \mathrm{g} / \mathrm{L})$

\begin{tabular}{|c|c|c|c|c|}
\hline & Standard & L-Harvest & L-Fruit & Sign \\
\hline Acetic acid & A & $17.99 \pm 0.36$ & $26.05 \pm 0.52$ & $* * *$ \\
\hline Furfural & A & $0.88 \pm 0.04$ & $0.74 \pm 0.03$ & $* *$ \\
\hline Furfural acetyl & $\mathrm{B}$ & $1.17 \pm 0.05$ & $1.90 \pm 0.08$ & $* * *$ \\
\hline Propionic acid & $\mathrm{A}$ & $0.27 \pm 0.01$ & $0.75 \pm 0.04$ & $* * *$ \\
\hline 5-methyl-furfural & $\mathrm{B}$ & $0.38 \pm 0.02$ & $1.50 \pm 0.07$ & $* * *$ \\
\hline$\gamma$-Butyrolactone & $\mathrm{A}$ & $3.34 \pm 0.20$ & $2.92 \pm 0.18$ & - \\
\hline Butyric acid & A & n.d. & $0.26 \pm 0.02$ & $* * *$ \\
\hline Furfuryl alcohol & A & $1.76 \pm 0.04$ & $2.11 \pm 0.04$ & $* * *$ \\
\hline 3-methyl butyric acid & A & n.d. & $0.36 \pm 0.02$ & $* * *$ \\
\hline 3,4-dimethyl-2(5H)-furanone & $\mathrm{B}$ & $0.36 \pm 0.01$ & $0.47 \pm 0.02$ & $* *$ \\
\hline $2(3 \mathrm{H})$-furanone & $\mathrm{B}$ & $3.90 \pm 0.20$ & $4.25 \pm 0.21$ & - \\
\hline Pentanoic acid & A & $0.11 \pm 0.01$ & $0.14 \pm 0.01$ & - \\
\hline Anethole & $\mathrm{A}$ & $1.06 \pm 0.06$ & $1.11 \pm 0.07$ & - \\
\hline Cyclotene & A & $0.40 \pm 0.03$ & $0.97 \pm 0.08$ & $* * *$ \\
\hline Hexanoic acid + Dihydromaltol & $\mathrm{B}$ & $0.56 \pm 0.04$ & $0.85 \pm 0.06$ & $* *$ \\
\hline Guaiacol & A & $0.54 \pm 0.04$ & $0.51 \pm 0.04$ & - \\
\hline 2-Phenylethanol & $\mathrm{A}$ & $3.32 \pm 0.30$ & $2.08 \pm 0.19$ & $* *$ \\
\hline trans- $\beta$-methyl- $\gamma$-octalactone & A & $0.74 \pm 0.06$ & $1.05 \pm 0.08$ & $* *$ \\
\hline cis- $\beta$-methyl- $\gamma$-octalactone & A & $1.94 \pm 0.14$ & $2.37 \pm 0.17$ & $*$ \\
\hline Methyl guaiacol & B & n.d. & $0.35 \pm 0.01$ & $* * *$ \\
\hline Maltol & A & $2.70 \pm 0.22$ & $4.82 \pm 0.39$ & $* * *$ \\
\hline Furyl-hydroxymethyl ketone & $\mathrm{B}$ & $0.52 \pm 0.03$ & $1.45 \pm 0.07$ & $* * *$ \\
\hline Furaneol & $\mathrm{A}$ & $0.59 \pm 0.01$ & $0.66 \pm 0.01$ & $* *$ \\
\hline Octanoic acid & A & $0.60 \pm 0.04$ & $0.94 \pm 0.06$ & $* * *$ \\
\hline Eugenol & $\mathrm{A}$ & $0.72 \pm 0.05$ & $0.66 \pm 0.05$ & - \\
\hline 4-Vinyl-guaiacol & B & $0.37 \pm 0.03$ & $0.44 \pm 0.03$ & - \\
\hline Syringol & A & $13.17 \pm 1.19$ & $12.01 \pm 1.08$ & - \\
\hline Isoeugenol & A & $0.60 \pm 0.04$ & $0.42 \pm 0.03$ & $* *$ \\
\hline 3,4-dihydro-3-oxo- $\alpha$-ionol I & B & $2.65 \pm 0.19$ & $1.87 \pm 0.13$ & $* *$ \\
\hline Benzoic acid & A & $3.02 \pm 0.18$ & $3.76 \pm 0.23$ & $*$ \\
\hline 3,4-dihydro-3-oxo- $\alpha$-ionol II & $\mathrm{B}$ & $1.67 \pm 0.08$ & $1.35 \pm 0.07$ & $* *$ \\
\hline 3,4-dihydro-3-oxo- $\alpha$-ionol III & $\mathrm{B}$ & $5.21 \pm 0.21$ & $4.23 \pm 0.17$ & $* *$ \\
\hline 5-hydroxymethyl-furfural & $\mathrm{A}$ & $41.14 \pm 2.06$ & $62.81 \pm 3.14$ & $* * *$ \\
\hline Vanillin & $\mathrm{B}$ & $57.79 \pm 2.31$ & $80.28 \pm 3.21$ & $* * *$ \\
\hline Dihydroeugenol & A & $2.32 \pm 0.14$ & $2.07 \pm 0.12$ & - \\
\hline Ethyl vanillate & A & $24.15 \pm 0.91$ & $18.86 \pm 0.71$ & $* * *$ \\
\hline Acetovanillone & A & $3.57 \pm 0.14$ & $2.46 \pm 0.10$ & $* * *$ \\
\hline Homovanillic alcohol & B & $18.55 \pm 0.93$ & $18.84 \pm 0.94$ & - \\
\hline Hexadecanoic acid & A & $7.05 \pm 0.28$ & $5.31 \pm 0.21$ & $* * *$ \\
\hline Syringic aldehyde & A & $281.67 \pm 11.27$ & $202.66 \pm 8.11$ & $* * *$ \\
\hline Dihydroconiferyl alcohol & B & $98.32 \pm 3.93$ & $82.09 \pm 3.28$ & $* *$ \\
\hline Coniferyl aldehyde & A & $11.26 \pm 0.68$ & $48.90 \pm 2.93$ & $* * *$ \\
\hline
\end{tabular}

n.d. not detected

" $A$ " in standard column indicate that compound is identified by reference standard and " $B$ " by library database or literature

Data are expressed as average \pm standard deviation $(n=3)$

Significant differences are indicated by $* *$ and $* * *$ at $p \leq 0.01$ and 0.001 respectively (Student's Indipendent-Samples T-test) 
Fig. $1{ }^{\circ}$ Brix and \% alcohol evolution during alcoholic fermentation of musts with and without added tannins in aqueous solution $(\mathrm{H}=\mathrm{L}-\mathrm{Har}-$ vest; $\mathrm{F}=\mathrm{L}$-Fruit) at different concentrations. $H 30 \mathrm{~L}$-Harvest at $30 \mathrm{~mL} / 100 \mathrm{~L}, \mathrm{H} 45 \mathrm{~L}-$ Harvest at $45 \mathrm{~mL} / 100 \mathrm{~L}, H 60 \mathrm{~L}-$ Harvest at $60 \mathrm{~mL} / 100 \mathrm{~L}, F 30 \mathrm{~L}$-Fruit at $30 \mathrm{~mL} / 100 \mathrm{~L}, F 45 \mathrm{~L}$-Fruit at $45 \mathrm{~mL} / 100 \mathrm{~L}, F 60 \mathrm{~L}-$ Fruit at $60 \mathrm{~mL} / 100 \mathrm{~L}$

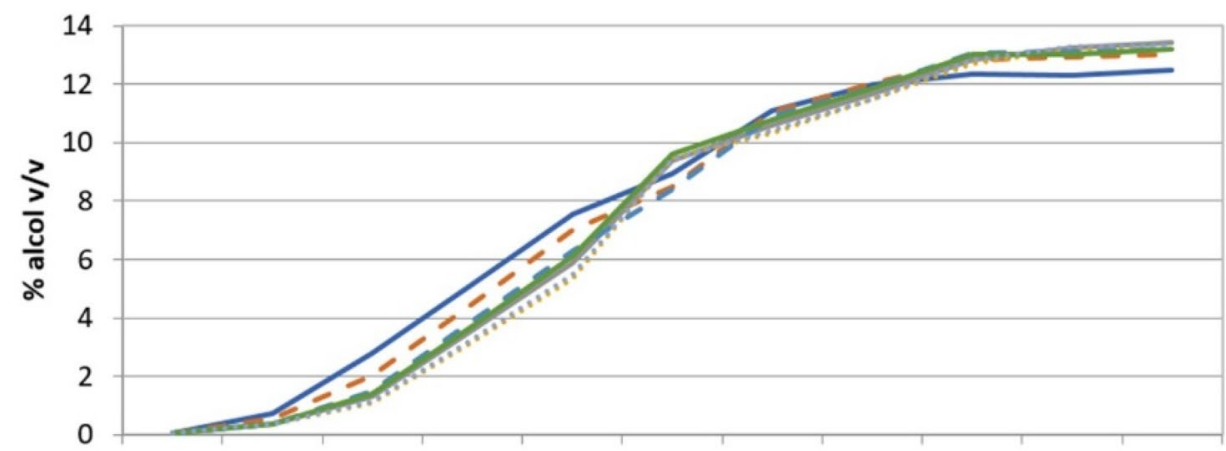

sep 04 sep 05 sep 06 sep 07 sep 08 sep 09 sep 10 sep 11 sep 12 sep 13 sep 14
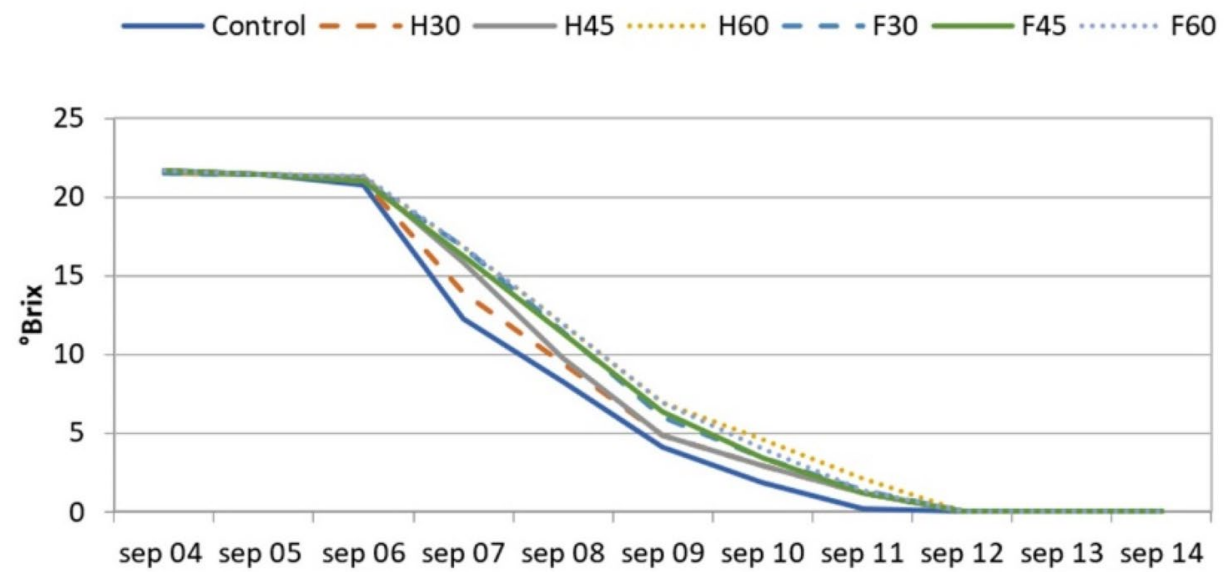

Table 3 Chemical-physical parameters and phenolic compounds of wines obtained with and without added tannins in aqueous solution $(\mathrm{H}=\mathrm{L}-$ Harvest; $\mathrm{F}=\mathrm{L}-$ Fruit $)$ at different concentrations

\begin{tabular}{|c|c|c|c|c|c|c|c|}
\hline & Control & $\mathrm{H} 30$ & H45 & $\mathrm{H} 60$ & F30 & F45 & F60 \\
\hline Ethanol $(\% \mathrm{w} / \mathrm{v})$ & $12.54 \pm 0.21$ & $13.03 \pm 0.24$ & $13.52 \pm 0.32$ & $13.52 \pm 0.31$ & $13.51 \pm 0.33$ & $13.46 \pm 0.38$ & $13.22 \pm 0.39$ \\
\hline $\mathrm{pH}$ & $3.07 \pm 0.03$ & $3.05 \pm 0.02$ & $3.04 \pm 0.02$ & $3.03 \pm 0.03$ & $3.03 \pm 0.02$ & $3.03 \pm 0.03$ & $3.03 \pm 0.02$ \\
\hline $\begin{array}{l}\text { Volatile acidity (g/L acetic } \\
\text { acid) }\end{array}$ & $0.18 \pm 0.01^{\mathrm{a}}$ & $0.20 \pm 0.01^{\mathrm{a}, \mathrm{b}}$ & $0.24 \pm 0.01^{\mathrm{d}}$ & $0.23 \pm 0.01^{\mathrm{c}, \mathrm{d}}$ & $0.21 \pm 0.02^{\mathrm{b}, \mathrm{c}}$ & $0.22 \pm 0.02^{b, c, d}$ & $0.22 \pm 0.01^{b, c, c}$ \\
\hline $\begin{array}{l}\text { Total acidity ( } \mathrm{g} / \mathrm{L} \text { tartaric } \\
\text { acid) }\end{array}$ & $6.93 \pm 0.21^{\mathrm{a}}$ & $7.09 \pm 0.22^{\mathrm{a}, \mathrm{b}}$ & $7.31 \pm 0.25^{\mathrm{c}, \mathrm{d}}$ & $7.36 \pm 0.27^{\mathrm{d}}$ & $7.38 \pm 0.32^{\mathrm{d}}$ & $7.28 \pm 0.29^{\mathrm{c}, \mathrm{d}}$ & $7.18 \pm 0.28^{\mathrm{b}, \mathrm{c}}$ \\
\hline Total $\mathrm{SO}_{2}(\mathrm{mg} / \mathrm{L})$ & $97.92 \pm 2.79^{\mathrm{e}}$ & $86.60 \pm 1.97^{\mathrm{a}}$ & $88.05 \pm 2.95^{\mathrm{a}, \mathrm{b}}$ & $95.88 \pm 2.89^{\mathrm{d}, \mathrm{e}}$ & $90.95 \pm 2.88^{\mathrm{b}, \mathrm{c}}$ & $93.85 \pm 2.99^{\mathrm{c}, \mathrm{d}}$ & $96.76 \pm 2.93^{\mathrm{d}, \mathrm{c}}$ \\
\hline Free $\mathrm{SO}_{2}(\mathrm{mg} / \mathrm{L})$ & $34.90 \pm 1.09^{\mathrm{b}}$ & $34.45 \pm 1.14^{\mathrm{a}}$ & $34.87 \pm 1.22^{\mathrm{b}}$ & $34.32 \pm 1.31^{\mathrm{a}}$ & $34.45 \pm 1.11^{\mathrm{a}}$ & $35.45 \pm 1.27^{\mathrm{c}}$ & $34.90 \pm 1.35^{\mathrm{b}}$ \\
\hline Acetaldehyde (mg/L) & $51.98 \pm 1.69^{\mathrm{a}}$ & $54.00 \pm 1.55^{\mathrm{a}, \mathrm{b}}$ & $59.19 \pm 1.46^{\mathrm{c}, \mathrm{d}}$ & $57.47 \pm 1.39^{\mathrm{b}, \mathrm{c}}$ & $56.90 \pm 1.22^{\mathrm{b}, \mathrm{c}}$ & $56.92 \pm 1.31^{\mathrm{b}, \mathrm{c}}$ & $59.75 \pm 1.28^{\mathrm{c}}$ \\
\hline $\begin{array}{l}\text { Flavan-3-ol by p-DAC assays } \\
\text { (mg/L }(+) \text { catechin })\end{array}$ & $11.08 \pm 0.24^{\mathrm{a}}$ & $13.55 \pm 0.35^{\mathrm{c}}$ & $14.30 \pm 0.38^{\mathrm{d}}$ & $15.06 \pm 0.42^{\mathrm{e}}$ & $12.32 \pm 0.28^{b}$ & $13.24 \pm 0.36^{\mathrm{c}}$ & $13.44 \pm 0.34^{\mathrm{c}}$ \\
\hline $\begin{array}{l}\text { Total Phenol (g/L (+)-cat- } \\
\text { echin) }\end{array}$ & $83.72 \pm 2.65^{\mathrm{a}}$ & $105.23 \pm 3.23^{b}$ & $109.87 \pm 3.35^{\mathrm{b}}$ & $106.79 \pm 3.75^{\mathrm{b}}$ & $152.50 \pm 4.22^{c}$ & $161.86 \pm 4.14^{\mathrm{d}}$ & $112.99 \pm 3.85^{b}$ \\
\hline
\end{tabular}

H30 L-Harvest at $30 \mathrm{~mL} / 100 \mathrm{~L}, H 45 \mathrm{~L}-H a r v e s t$ at $45 \mathrm{~mL} / 100 \mathrm{~L}, H 60 \mathrm{~L}-\mathrm{Harvest}$ at $60 \mathrm{~mL} / 100 \mathrm{~L}$, F30 L-Fruit at $30 \mathrm{~mL} / 100 \mathrm{~L}, F 45 \mathrm{~L}-\mathrm{Fruit}$ at $45 \mathrm{~mL} / 100 \mathrm{~L}, F 60 \mathrm{~L}-$ Fruit at $60 \mathrm{~mL} / 100 \mathrm{~L}$

Different Latin letters within the same row indicate significant differences $(p<0.05)$

of this class, and its presence showed that the must was subjected to enzymatic oxidation (due to polyphenol oxidase), probably in a destemmer-crusher and/or in a pneumatic press $[35,56]$, before adding the tannins in solution and, therefore, the GRP content is not related to the addition of the tannins. In fact, when caftaric acid is oxidized to its corresponding quinone by tyrosinase, glutathione (GSH) reacts rapidly with quinone to form a GRP, which is no longer a substrate for 


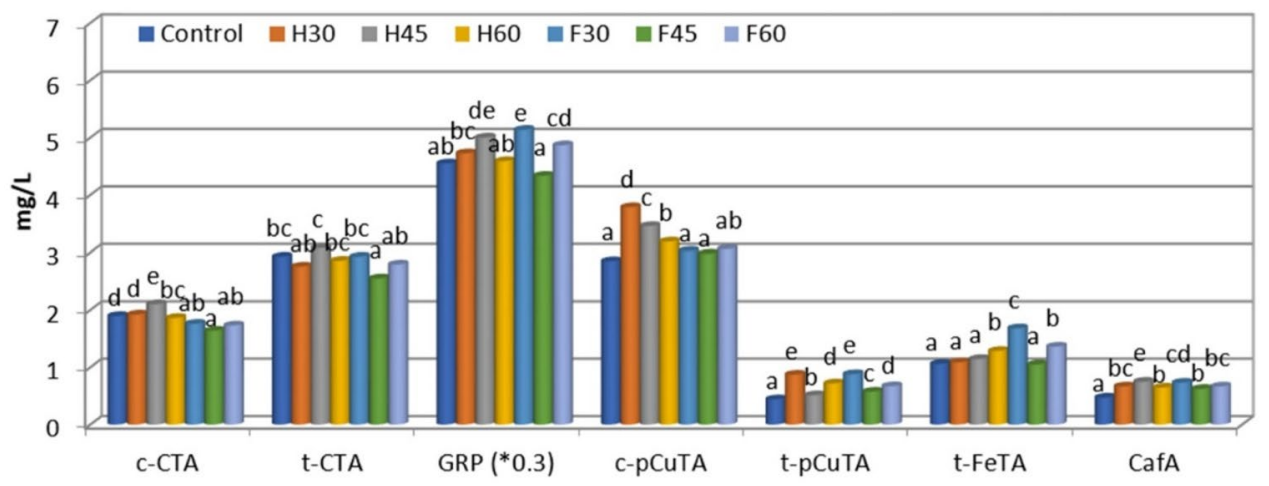

Fig. 2 Hydroxycinnamoyl tartaric acids, GRP and free caffeic acid in wines control and with the addition of tannins in aqueous solution $(\mathrm{H}=\mathrm{L}-$ Harvest; $\mathrm{F}=\mathrm{L}$-Fruit $)$ at different concentrations. H30 L-Harvest at $30 \mathrm{~mL} / 100 \mathrm{~L}, H 45 \mathrm{~L}-H a r v e s t$ at $45 \mathrm{~mL} / 100 \mathrm{~L}, H 60 \mathrm{~L}-\mathrm{Har}-$ vest at $60 \mathrm{~mL} / 100 \mathrm{~L}, F 30 \mathrm{~L}-F r u i t$ at $30 \mathrm{~mL} / 100 \mathrm{~L}, F 45 \mathrm{~L}$-Fruit at

further oxidation by grape polyphenol oxidase $[57,58]$. The GRP content is different between the tests with and without tannins in solution since the formation of this compound occurred before their addition in the mashing phases due to the presence of oxygen and lipoxygenase enzymes.

\section{Aromatic volatile compounds of wines}

The concentrations of the higher alcohols are shown in Fig. 3. Isoamyl alcohol and, above all, ethyl acetate were in higher quantities in the control wine $(p<0.05)$, where the fermentation process was faster. These results are in line with those of Chen et al. [59], which showed that oak tannins inhibit the development of higher alcohols. The content of 1-propanol, which is mostly influenced by the initial nitrogen concentration in the must [60], showed slight differences between the control wines and the trials, even though they received the same amount of nitrogen $(p<0.05)$.

The quantities of volatile fermentation compounds (Table 4 and Table S1), responsible for the fresh fruit
$45 \mathrm{~mL} / 100 \mathrm{~L}, F 60 \mathrm{~L}-F r u i t$ at $60 \mathrm{~mL} / 100$ L. $c, t$-CTA cis,trans-caffeoyl tartaric acid, c,t-pCuTA cis,trans-p-coumaroyl tartaric acid, GRP grape reaction product, $t$-FeTA trans-ferulil tartaric acid, CafA free Caffeic acid. *GRP concentration was multiplied by 0.3 . Different letters indicate significant differences $(p<0.05)$

taste (banana, apple, pear and fruity in general) and floral aromas (rose) suggest that the tests with tannins in aqueous solution tend to be richer in fermentation esters (2-ethyl hexanoate, ethyl octanoate, ethyl decanoate, ethyl 9-decenoate, ethyl 3-phenyl-2-OH-propionate) $(p<0.05)$. The content of medium-chain fatty acids (hexanoic, octanoic and decanoic) is slightly higher $(p<0.05)$ in some of the tests with tannins in aqueous solution, although it is not possible to detect a particular trend. The content of 9-decenoic and dodecanoic acids was significantly higher $(p<0.05)$ in tests with the addition of L-Harvest and L-Fruit. Higher acetate alcohols (isoamyl acetate, hexyl acetate), except 2-phenylethyl acetate, and pre-fermentative alcohols (hexanol, trans-3-hexenol, cis-3-hexenol), were found in higher amounts in the tests $(p<0.05)$ than in the control. Volatile compounds directly deriving by water solution tannins were found to be negligible in all trials where the additions of both L-Harvest and L-Fruit were performed (Table 4). Among these, only vanillin, eugenol, and omovanillic and dihydroconiferyl alcohols

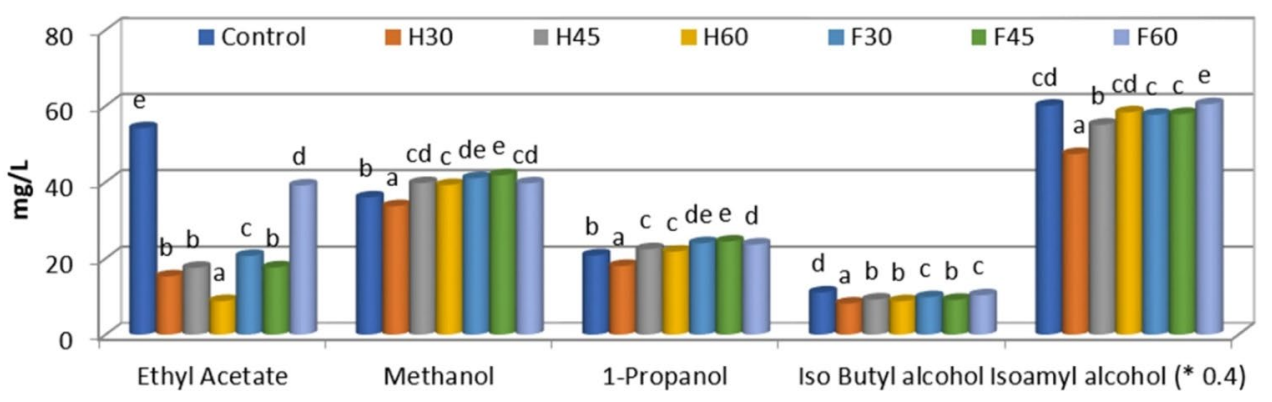

Fig. 3 Ethyl acetate, methanol and higher alcohols in wines control and with the addition of tannins in aqueous solution $(\mathrm{H}=\mathrm{L}-\mathrm{Harvest}$; $\mathrm{F}=\mathrm{L}-$ Fruit) at different concentrations. $\mathrm{H} 30 \mathrm{~L}-\mathrm{Harvest}$ at $30 \mathrm{~mL} / 100$ $\mathrm{L}, H 45 \mathrm{~L}-H a r v e s t$ at $45 \mathrm{~mL} / 100 \mathrm{~L}, H 60$ L-Harvest at $60 \mathrm{~mL} / 100$
L, F30 L-Fruit at $30 \mathrm{~mL} / 100 \mathrm{~L}, F 45 \mathrm{~L}-F r u i t$ at $45 \mathrm{~mL} / 100 \mathrm{~L}, F 60$ L-Fruit at $60 \mathrm{~mL} / 100 \mathrm{~L}$. Different Latin letters indicate significant differences $(p<0.05)$ 
Table 4 Volatile organic compounds in wines $(\mu \mathrm{g} / \mathrm{L})$ control and with the addition of tannins in aqueous solution $(\mathrm{H}=\mathrm{L}-\mathrm{Harvest}$; F $=\mathrm{L}-\mathrm{Fruit})$ at different concentrations

\begin{tabular}{|c|c|c|c|c|c|c|c|c|}
\hline & Standard & Control & $\mathrm{H} 30$ & H45 & H60 & $\mathrm{F} 30$ & F45 & F60 \\
\hline \multicolumn{9}{|l|}{ Esters } \\
\hline Isoamyl acetate & A & $3679.22^{\mathrm{a}}$ & $4359.14^{\mathrm{b}}$ & $4440.64^{\mathrm{b}}$ & $4879.01^{\mathrm{c}}$ & $4310.86^{\mathrm{b}}$ & $4209.63^{\mathrm{b}}$ & $3413.39^{\mathrm{a}}$ \\
\hline Ethyl hexanoate & A & 722.25 & 746.27 & 717.09 & 786.16 & 751.96 & 769.12 & 709.39 \\
\hline Hexyl acetate & A & $267.82^{\mathrm{b}}$ & $302.93^{c}$ & $271.15^{\mathrm{b}}$ & $332.19^{d}$ & $253.11^{\mathrm{a}, \mathrm{b}}$ & $266.74^{\mathrm{b}}$ & $229.94^{\mathrm{a}}$ \\
\hline Ethyl lactate & A & $128.41^{\mathrm{b}, \mathrm{c}}$ & $122.68^{\mathrm{a}, \mathrm{b}}$ & $121.90^{\mathrm{a}, \mathrm{b}}$ & $110.31^{\mathrm{a}}$ & $190.89^{\mathrm{e}}$ & $153.45^{\mathrm{d}}$ & $138.27^{\mathrm{c}}$ \\
\hline Ethyl octanoate & A & $1097.31^{\mathrm{a}, \mathrm{b}}$ & $1117.44^{\mathrm{a}, \mathrm{b}}$ & $1077.95^{\mathrm{a}}$ & $1401.51^{\mathrm{e}}$ & $1280.05^{\mathrm{c}, \mathrm{d}}$ & $1372.69^{\mathrm{d}, \mathrm{e}}$ & $1195.12^{\mathrm{b}, \mathrm{c}}$ \\
\hline Ethyl 3-OH-butyrate & B & $32.61^{\mathrm{a}}$ & $36.24^{\mathrm{a}, \mathrm{b}}$ & $43.71^{\mathrm{c}}$ & $51.95^{\mathrm{e}}$ & $48.40^{\mathrm{d}, \mathrm{e}}$ & $46.20^{\mathrm{c}, \mathrm{d}}$ & $37.79^{\mathrm{b}}$ \\
\hline Ethyl decanoate & A & $291.30^{\mathrm{a}}$ & $300.05^{\mathrm{a}, \mathrm{b}}$ & $276.93^{\mathrm{a}}$ & $570.35^{\mathrm{d}}$ & $362.41^{\mathrm{b}}$ & $430.03^{c}$ & $363.75^{\mathrm{b}}$ \\
\hline Diethyl succinate & A & $660.51^{\mathrm{a}}$ & $689.15^{\mathrm{a}}$ & $911.41^{\mathrm{b}}$ & $954.21^{\mathrm{b}}$ & $1254.13^{\mathrm{c}}$ & $1306.46^{\mathrm{c}}$ & $1324.92^{\mathrm{c}}$ \\
\hline Ethyl 9-decenoate & $\mathrm{B}$ & $40.67^{\mathrm{b}}$ & $32.89^{\mathrm{a}}$ & $42.46^{\mathrm{b}}$ & $63.06^{\mathrm{c}}$ & $30.66^{\mathrm{a}}$ & $34.51^{\mathrm{a}}$ & $77.47^{\mathrm{d}}$ \\
\hline 2-Phenylethyl acetate & A & $635.07^{\mathrm{d}}$ & $613.07^{\mathrm{c}, \mathrm{d}}$ & $570.48^{\mathrm{b}, \mathrm{c}}$ & $674.94^{\mathrm{d}}$ & $534.14^{\mathrm{b}}$ & $540.06^{\mathrm{b}}$ & $421.75^{\mathrm{a}}$ \\
\hline Anethole & A & n.d. ${ }^{\mathrm{a}}$ & $20.96^{\mathrm{c}}$ & $21.76^{\mathrm{c}}$ & $30.25^{\mathrm{e}}$ & $14.49^{\mathrm{b}}$ & $20.22^{\mathrm{c}}$ & $24.34^{\mathrm{d}}$ \\
\hline 2-Ethyl-hexanoic acid & B & $202.34^{\mathrm{e}}$ & $176.67^{\mathrm{c}, \mathrm{d}}$ & $150.40^{\mathrm{a}}$ & $189.02^{\mathrm{d}, \mathrm{e}}$ & $154.76^{\mathrm{a}, \mathrm{b}}$ & $162.58^{\mathrm{a}, \mathrm{b}, \mathrm{c}}$ & $168.29^{\mathrm{b}, \mathrm{c}}$ \\
\hline Diethyl malate & A & $177.45^{\mathrm{b}}$ & $153.54^{\mathrm{a}}$ & $140.79^{\mathrm{a}}$ & $221.36^{\mathrm{c}}$ & $230.94^{\mathrm{c}, \mathrm{d}}$ & $255.09^{\mathrm{e}}$ & $245.43^{\text {de }}$ \\
\hline Isoamyl-4-OH-butyrate & $\mathrm{B}$ & $14.17^{\mathrm{b}}$ & $11.99^{\mathrm{a}}$ & $16.60^{\mathrm{c}}$ & $15.25^{\mathrm{b}, \mathrm{c}}$ & $15.20^{\mathrm{b}, \mathrm{c}}$ & $15.77^{\mathrm{c}}$ & $16.20^{\mathrm{c}}$ \\
\hline Ethyl-3-phenyl-2-OH-propanoato & B & $55.92^{\mathrm{b}}$ & $49.93^{\mathrm{a}}$ & $57.18^{\mathrm{b}}$ & $63.54^{\mathrm{c}}$ & $56.10^{\mathrm{b}}$ & $56.81^{\mathrm{b}}$ & $64.50^{\mathrm{c}}$ \\
\hline Monoethylsuccinic acid & $\mathrm{B}$ & $1669.84^{\mathrm{c}}$ & $1428.29^{b}$ & $1225.58^{\mathrm{a}}$ & $1147.42^{\mathrm{a}}$ & $1387.70^{\mathrm{b}}$ & $1500.31^{\mathrm{b}}$ & $1825.34^{\mathrm{d}}$ \\
\hline Total esters & & $9675^{\mathrm{a}}$ & $10,161^{\mathrm{b}}$ & $10,086^{\mathrm{b}}$ & $11,491^{\mathrm{d}}$ & $10,876^{\mathrm{c}}$ & $11,140^{\mathrm{d}}$ & $10,256^{\mathrm{b}, \mathrm{c}}$ \\
\hline \multicolumn{9}{|l|}{ Alcohols } \\
\hline 3-Methyl-pentan-1-ol & & $37.19^{\mathrm{a}}$ & $49.36^{\mathrm{b}, \mathrm{c}, \mathrm{d}}$ & $40.91^{\mathrm{a}, \mathrm{b}}$ & $55.85^{\mathrm{d}}$ & $50.64^{\mathrm{c}, \mathrm{d}}$ & $43.41^{\mathrm{a}, \mathrm{b}, \mathrm{c}}$ & $45.60^{\mathrm{a}, \mathrm{b}, \mathrm{c}}$ \\
\hline Hexan-1-ol & A & $609.92^{\mathrm{a}}$ & $619.89^{\mathrm{a}, \mathrm{b}}$ & $699.97^{\mathrm{b}, \mathrm{c}}$ & $765.17^{\mathrm{c}}$ & $734.21^{\mathrm{b}, \mathrm{c}}$ & $729.22^{\mathrm{b}, \mathrm{c}}$ & $670.69^{\mathrm{a}, \mathrm{b}}$ \\
\hline trans-3-Hexen-1-ol & A & $41.61^{\mathrm{a}}$ & $45.69^{\mathrm{a}, \mathrm{b}}$ & $52.40^{\mathrm{b}, \mathrm{c}}$ & $46.98^{\mathrm{a}, \mathrm{b}}$ & $58.37^{\mathrm{c}}$ & $52.32^{\mathrm{b}, \mathrm{c}}$ & $52.73^{\mathrm{b}, \mathrm{c}}$ \\
\hline cis-3-Hexen-1-ol & A & $64.43^{b}$ & $64.37^{\mathrm{b}}$ & $80.66^{\mathrm{c}}$ & $48.48^{\mathrm{a}}$ & $90.66^{\mathrm{c}}$ & $82.69^{c}$ & $80.75^{\mathrm{c}}$ \\
\hline 2-Phenylethanol & A & $13,208.51$ & $13,589.42$ & $11,681.53$ & $13,032.84$ & $13,866.89$ & $14,264.43$ & $13,754.43$ \\
\hline Eugenol & A & n.d. ${ }^{\mathrm{a}}$ & $0.91^{\mathrm{b}}$ & $2.39^{c}$ & $6.16^{\mathrm{f}}$ & $5.82^{\mathrm{f}}$ & $2.78^{\mathrm{d}}$ & $5.17^{\mathrm{e}}$ \\
\hline 4-Vinylguaiacol & B & $153.28^{\mathrm{a}}$ & $171.66^{\mathrm{a}}$ & $174.49^{\mathrm{a}}$ & $259.10^{\mathrm{b}}$ & $171.87^{\mathrm{a}}$ & $172.53^{\mathrm{a}}$ & $170.76^{\mathrm{a}}$ \\
\hline Homovanillic alcohol & B & n.d. ${ }^{\mathrm{a}}$ & $9.36^{\mathrm{b}}$ & $12.06^{\mathrm{c}}$ & $18.36^{\mathrm{e}}$ & $19.95^{\mathrm{f}}$ & $14.28^{\mathrm{d}}$ & $9.94^{\mathrm{b}}$ \\
\hline Dihydroconiferyl alcohol & B & n.d. ${ }^{\mathrm{a}}$ & $15.34^{\mathrm{c}}$ & $17.84^{\mathrm{d}}$ & $37.48^{\mathrm{g}}$ & $11.31^{\mathrm{b}}$ & $24.71^{\mathrm{f}}$ & $20.83^{c}$ \\
\hline Total alcohols & & $14,115^{b}$ & $14,566^{\mathrm{b}}$ & $12,762^{\mathrm{a}}$ & $14,270^{\mathrm{b}}$ & $15,010^{\mathrm{c}}$ & $15,386^{\mathrm{c}}$ & $14,811^{\mathrm{c}}$ \\
\hline \multicolumn{9}{|l|}{ Acids } \\
\hline Isovalerianic acid & A & $84.07^{\mathrm{c}}$ & $69.78^{\mathrm{b}}$ & $65.07^{\mathrm{a}, \mathrm{b}}$ & $79.27^{\mathrm{c}}$ & $66.08^{\mathrm{a}, \mathrm{b}}$ & $67.74^{\mathrm{b}}$ & $60.81^{\mathrm{a}}$ \\
\hline Hexanoic acid & A & $2966.36^{\mathrm{a}}$ & $2959.95^{\mathrm{a}}$ & $3160.36^{\mathrm{a}}$ & $3922.08^{\mathrm{c}}$ & $3196.78^{\mathrm{a}}$ & $3465.12^{\mathrm{b}}$ & $3124.59^{\mathrm{a}}$ \\
\hline Octanoic acid & A & $6368.61^{\mathrm{a}}$ & $6058.28^{\mathrm{a}}$ & $6330.08^{\mathrm{a}}$ & $7820.26^{\mathrm{c}}$ & $6567.68^{\mathrm{a}}$ & $7170.36^{\mathrm{b}}$ & $6209.08^{\mathrm{a}}$ \\
\hline Decanoic acid & A & $2076.02^{\mathrm{a}}$ & $2221.18^{\mathrm{a}}$ & $2255.85^{\mathrm{a}, \mathrm{b}}$ & $3989.69^{c}$ & $2104.36^{\mathrm{a}}$ & $2465.45^{\mathrm{b}}$ & $2308.31^{\mathrm{a}, \mathrm{b}}$ \\
\hline 9-decenoic acid & A & $244.18^{c}$ & $195.49^{\mathrm{b}}$ & $240.37^{\mathrm{c}}$ & $322.47^{\mathrm{d}}$ & $170.84^{\mathrm{a}}$ & $167.97^{\mathrm{a}}$ & $330.73^{\mathrm{d}}$ \\
\hline Dodecanoic acid & A & $38.82^{\mathrm{b}}$ & $76.92^{\mathrm{e}}$ & $28.22^{\mathrm{a}}$ & $58.17^{\mathrm{c}}$ & $57.78^{c}$ & $65.87^{\mathrm{d}}$ & $29.23^{\mathrm{a}}$ \\
\hline Total acids & & $11,778^{a}$ & $11,582^{\mathrm{a}}$ & $12,080^{\mathrm{b}}$ & $16,192^{\mathrm{d}}$ & $12,164^{\mathrm{b}}$ & $13,403^{\mathrm{c}}$ & $12,063^{\mathrm{b}}$ \\
\hline \multicolumn{9}{|l|}{ Lactones } \\
\hline trans- $\beta$-methyl- $\gamma$-octalactone & A & $\mathrm{n} \cdot \mathrm{d}^{\mathrm{a}}$ & n.d. ${ }^{a}$ & n.d. ${ }^{a}$ & $21.85^{\mathrm{c}}$ & n.d. ${ }^{a}$ & n.d. ${ }^{a}$ & $16.57^{b}$ \\
\hline \multicolumn{9}{|l|}{ Aldehydes } \\
\hline Vanillin & A & n.d. ${ }^{\mathrm{a}}$ & n.d. ${ }^{\mathrm{a}}$ & $14.14^{\mathrm{d}}$ & $15.59^{\mathrm{e}}$ & n.d. ${ }^{\mathrm{a}}$ & $9.05^{\mathrm{b}}$ & $10.35^{\mathrm{c}}$ \\
\hline
\end{tabular}

H30 L-Harvest at $30 \mathrm{~mL} / 100 \mathrm{~L}, H 45 \mathrm{~L}-$ Harvest at $45 \mathrm{~mL} / 100 \mathrm{~L}, H 60 \mathrm{~L}-$ Harvest at $60 \mathrm{~mL} / 100 \mathrm{~L}$, F30 L-Fruit at $30 \mathrm{~mL} / 100 \mathrm{~L}$, F45 L-Fruit at $45 \mathrm{~mL} / 100 \mathrm{~L}, F 60 \mathrm{~L}-$ Fruit at $60 \mathrm{~mL} / 100 \mathrm{~L}$

" $A$ " in standard column indicate that compound is identified by reference standard and " $B$ " by library database or literature

Different Latin letters within the same row indicate significant differences $(p<0.05)$ 
Table 5 Duo-trio test and preference test of wines control and with the addition of tannins in aqueous solution $(\mathrm{H}=\mathrm{L}-\mathrm{Harvest}$; F $=\mathrm{L}-\mathrm{Fruit})$ at different concentrations

\begin{tabular}{|c|c|c|c|c|c|c|}
\hline & Control vs H30 & Control vs H45 & Control vs H60 & Control vs F30 & Control vs F45 & Control vs F60 \\
\hline \multicolumn{7}{|l|}{ Duo-trio test } \\
\hline $\begin{array}{l}\text { Numbers of cor- } \\
\text { rect judgements }\end{array}$ & 15 & $17 *$ & $17 *$ & 15 & 13 & $19 * *$ \\
\hline \multicolumn{7}{|l|}{ Preference test } \\
\hline $\begin{array}{l}\text { Number of } \\
\text { preferences for } \\
\text { each trials }\end{array}$ & $\begin{array}{ll}9 & 15\end{array}$ & $9 \quad 15$ & $6 \quad 1^{*}$ & 14 & 13 & $5 \quad 19 * *$ \\
\hline
\end{tabular}

number of panelists 24

H30 L-Harvest at $30 \mathrm{~mL} / 100 \mathrm{~L}, H 45 \mathrm{~L}-$ Harvest at $45 \mathrm{~mL} / 100 \mathrm{~L}, H 60 \mathrm{~L}-\mathrm{Harvest}$ at $60 \mathrm{~mL} / 100 \mathrm{~L}$, F30 L-Fruit at $30 \mathrm{~mL} / 100 \mathrm{~L}$, F45 L-Fruit at $45 \mathrm{~mL} / 100 \mathrm{~L}, F 60 \mathrm{~L}-$ Fruit at $60 \mathrm{~mL} / 100 \mathrm{~L}$

Significant differences between treatments are indicated by $*$ and $* *$ at $p \leq 0.05$ and 0.01 respectively

were identified and their concentration resulted proportional to the dosage of water solution tannins added to musts $(p<0.05)$.

\section{Sensory profile of wines}

The results of the duo-trio test (Table 5) showed that, out of six sessions, three showed significant differences $(p<0.01$ and $p<0.05)$ between the control wine and each test with tannins in aqueous solution. Great differences emerged in the comparison between the control wine and the trials with 45 and $60 \mathrm{~g} / 100 \mathrm{~L}$ of L-Harvest (H45 and H60) and the trial with $60 \mathrm{~g} / 100 \mathrm{~L}$ of L-Fruit (F60). During the duo-trial, the preference test was also carried out. This last test showed that samples with the two tannins in aqueous solution were always preferred to control wine (Table 5). Significant differences, at the level of 1 and $5 \%$, emerged in the comparison between the control wine and the tests with $60 \mathrm{~g} / 100 \mathrm{~L}$ of both L-Harvest (H60) and L-Fruit (F60). The statistical processing of the comparison data of the control wine selection tests and of each group of three tests (H30, H45, H60 and F30, F45, F60) showed significant differences between the tests, for each sensory descriptor considered (Figs. 4a, b). As regards the visual descriptor, the intensity of colour was perceived with less intensity in the control wine, and with increasing intensity in the tests with L-Harvest and L-Fruit, depending on the added dose. These results highlighted the action of the integration of oak tannins on the increase in colour intensity and the formation of polymerized pigments [54]. As regards the olfactory and taste descriptors, fruit intensity, complexity and taste persistence were always perceived with greater intensity in the L-Harvest and L-Fruit trials. Olfactory and taste preference were also higher in the tests than in the control wine. It can therefore be concluded that the olfactory and taste components benefit from the use of tannins in aqueous solution, as they contribute to enhance the fermentation activity of the yeasts and as they bring greater sensory complexity to the wine.

\section{Conclusion}

The analytical determination of aqueous solution tannins extracted from oak wood revealed significant differences in the total colloids, resulting from the de-polymerization of wood polysaccharides, in the polyphenols content and in ellagitannins. These compounds were found in higher amounts in L-Harvest tests than in L-Fruit. Several volatile compounds were also detected and identified, partly already present in free form in oak wood and partly resulting from drying/maturing and roasting methods used in barrel production. L-Harvest had a higher concentration of phenolic aldehydes and volatile phenols, while furfural and piranic derivatives were found mainly in L-Fruit.

Alcoholic fermentation was partially facilitated by the occurring of water solution tannins. Wines obtained showed higher content of medium-chain fatty acid ethyl esters (ethyl hexanoate, ethyl octanoate and ethyl decanoate) and, in some instances, higher alcohols acetates, relevant for olfactory sensations provided to wines [59].

The higher alcohols (mainly isoamyl alcohol) and ethyl acetate were higher in the control wine, while the 2-phenyl ethanol, which provides an appreciable floral rose aroma [61] was higher in trials with tannins in aqueous solution. The total acidity was higher in wines treated with tannins, which showed a protective effect against the precipitation of potassium bitartrate crystals, probably due to polysaccharides present in tannin preparations. The sensory 
Fig. 4 - Sorting Test of wines control and with the addition of tannins in aqueous solution $(\mathrm{H}=\mathrm{L}-$ Harvest; $\mathrm{F}=\mathrm{L}-$ Fruit $)$ at different concentrations. H3O L-Harvest at $30 \mathrm{~mL} / 100 \mathrm{~L}$, H45 L-Harvest at $45 \mathrm{~mL} / 100$ $\mathrm{L}, H 60 \mathrm{~L}-$ Harvest at $60 \mathrm{~mL} / 100$ L, F30 L-Fruit at $30 \mathrm{~mL} / 100$ $\mathrm{L}, F 45 \mathrm{~L}-F r u i t$ at $45 \mathrm{~mL} / 100 \mathrm{~L}$, F60 L-Fruit at $60 \mathrm{~mL} / 100 \mathrm{~L}$. Different Latin letters indicate significant differences $(p<0.05)$
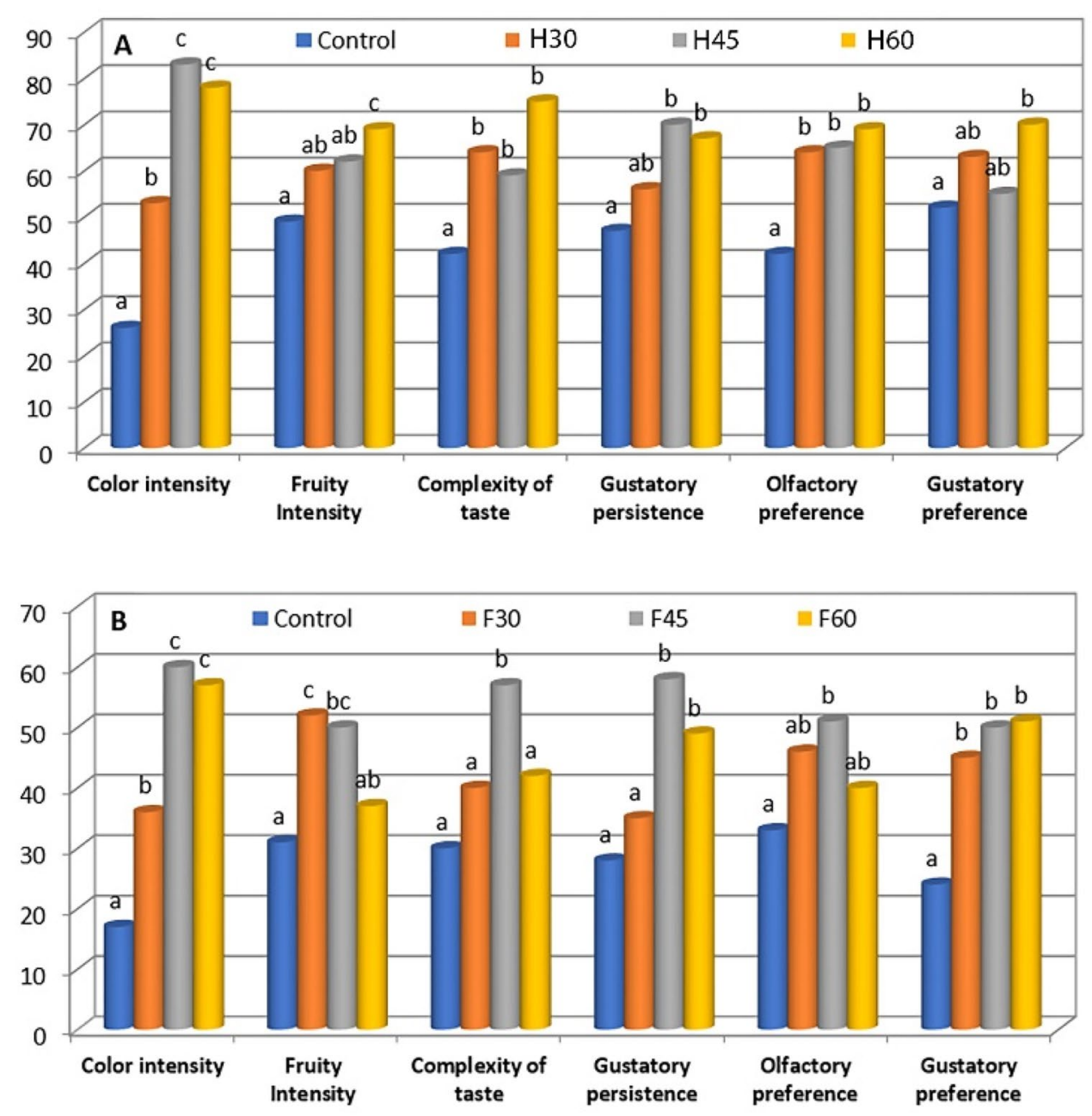

evaluation of the wines showed significant differences with the increase in the dosages of tannins in aqueous solution. In particular, they gave rise to more complex wines with greater volume, greater fruit intensity, elegance and aromatic persistence. In addition, samples with the addition of tannins were preferred to control wine, both in terms of olfactory and taste profile.

Based on the above data, it was found that the use of tannins in aqueous solution in must before alcoholic fermentation was beneficial both for the kinetics of alcoholic fermentation and for the sensory complexity and persistence of the wines obtained.

In conclusion, the addition of liquid tannins to Grillo white wines has guaranteed a greater olfactory complexity and fullness of taste. Moreover such added compounds could ensure a longer duration of the above mentioned qualitative characteristics of white wines over time.

Supplementary Information The online version contains supplementary material available at https://doi.org/10.1007/s00217-020-03668-9.
Acknowledgments The authors wish to thank Luigi Scavone, enterprise owner HTS enologia (Marsala, Trapani, Italy), for its technical support during winemaking process and together Roberto Plodari and Alessandro Castioni (company I-Oak S.r.l., 25020 Dello, Brescia, Italy) for them significant support to produce aqueous solution tannins, nutrient adjuvatns and oenological adjuvants.

Author contributions OC Supervision, investigation, conceptualization, funding acquisition, writing original draft; PB Investigation; DD Resources; LC Supervision, conceptualization, writing-review \& editing. All authors have read and agree to the published version of the manuscript.

Funding Open Access funding provided by Università degli Studi di Palermo. This work was supported by HTS Enologia of Luigi Scavone (Marsala, Trapani, Sicily, Italy) and I-Oak S.r.l. of Roberto Plodari (25020, Dello, Brescia, Italy).

\section{Compliance with ethical standards}

Conflict of interest The author Onofrio Corona received a research grants from HTS Enologia. Paola Bambina and Luciano Cinquanta declare that they have no conflict of interest. Author Diego De Filippi 
has been involved as a consultant and expert witness in Company HTS enologia.

Compliance with ethics requirements This article does not contain any studies with human participants or animals performed by any of the authors.

Open Access This article is licensed under a Creative Commons Attribution 4.0 International License, which permits use, sharing, adaptation, distribution and reproduction in any medium or format, as long as you give appropriate credit to the original author(s) and the source, provide a link to the Creative Commons licence, and indicate if changes were made. The images or other third party material in this article are included in the article's Creative Commons licence, unless indicated otherwise in a credit line to the material. If material is not included in the article's Creative Commons licence and your intended use is not permitted by statutory regulation or exceeds the permitted use, you will need to obtain permission directly from the copyright holder. To view a copy of this licence, visit http://creativecommons.org/licenses/by/4.0/.

\section{References}

1. Mueller-Harvey I (2001) Analysis of hydrolysable tannins. Anim Feed Sci Tech 91(1-2):3-20. https://doi.org/10.1016/s03778401(01)00227-9

2. Codex Alimentarius Commission (2009) Joint FAO/WHO food standards program Report of the forty-first session of the Codex Committee on Food Additives: Shanghai, China, 16-20 March 2009. Rome, FAO/WHO

3. Codex Alimentarius Commission 2016. Max Planck Encyclopedia of Public International Law. https://doi.org/10.1093/law:epil/ 9780199231690/e1857

4. OIV. International Oenological Codex. COEI-1-TANINS: 2015. http://www.oiv.int/

5. Cíchová M, Petříček J, Fiala J (2008) Influence of tannin addition on the content and composition of polyphenolic compounds in wines. Czech J Food Sci 26:33-38. https://doi.org/10.17221/242/ 2008-cjfs

6. Khanbabaee K, Ree TV (2010) ChemInform abstract: tannins: classification and definition. ChemInform. https://doi.org/10. 1002/chin.200213268

7. Versari A, du Toit W, Parpinello G (2013) Oenological tannins: a review. Aust J Grape Wine Res 19(1):1-10. https://doi.org/10. 1111/ajgw.12002

8. Comandini P, Lerma-García MJ, Simó-Alfonso EF, Toschi TG (2014) Tannin analysis of chestnut bark samples (Castanea sativa Mill.) by HPLC-DAD-MS. Food Chem 157:290-295. https://doi. org/10.1016/j.foodchem.2014.02.003

9. Pascual O, Vignault A, Gombau J, Navarro M, Gómez-Alonso S, García-Romero E, Miquel Canals J, Hermosín-Gutíerrez I, Teissedre P-L, Zamora F (2017) Oxygen consumption rates by different oenological tannins in a model wine solution. Food Chem 234:26-32. https://doi.org/10.1016/j.foodchem.2017.04.148

10. Vignault A, Pascual O, Jourdes M, Moine V, Fermaud M, Roudet J, Canals JM, Teissedre PL, Zamora F (2019) Impact of enological tannins on laccase activity. OENO One https://doi.org/10.20870/ oeno-one.2019.53.1.2361

11. He F, Pan Q-H, Shi Y, Duan C-Q (2008) Chemical synthesis of proanthocyanidins in vitro and their reactions in aging wines. Molecules 13(12):3007-3032. https://doi.org/10.3390/molecules1 3123007
12. Schofield P, Mbugua D, Pell A (2001) Analysis of condensed tannins: a review. Anim Feed Sci Tech 91(1-2):21-40. https://doi. org/10.1016/s0377-8401(01)00228-0

13. Tian R, Suo H, Zhang S, Sun B (2020) Separation of a family of antioxidants favan-3-ol thio-conjugates from procyanidins by high-speed counter-current chromatography. Eur Food Res Technol 246:1017-1029. https://doi.org/10.1007/s00217-020-03465-4

14. Serrano J, Puupponen-Pimiä R, Dauer A, Aura A-M, SauraCalixto F (2009) Tannins: Current knowledge of food sources intake bioavailability and biological effects. Mol Nutr Food Res. https://doi.org/10.1002/mnfr.200900039

15. Ferreira D, Slade D (2010) Oligomeric proanthocyanidins: naturally occurring O-Heterocycles. ChemInform. https://doi.org/10. 1002/chin.200252254

16. Salminen J-P, Ossipov V, Loponen J, Haukioja E, Pihlaja K (1999) Characterisation of hydrolysable tannins from leaves of Betula pubescens by high-performance liquid chromatography-mass spectrometry. J Chromatogr A 864(2):283-291. https://doi.org/ 10.1016/s0021-9673(99)01036-5

17. Mämmelä P, Savolainen H, Lindroos L, Kangas J, Vartiainen T (2000) Analysis of oak tannins by liquid chromatography-electrospray ionisation mass spectrometry. J Chromatogr A 891(1):7583. https://doi.org/10.1016/s0021-9673(00)00624-5

18. Vivas N, Nonier M-F, Gaulejac NVD, Absalon C, Bertrand A, Mirabel M (2004) Differentiation of proanthocyanidin tannins from seeds, skins and stems of grapes (Vitis vinifera) and heartwood of Quebracho (Schinopsis balansae) by matrix-assisted laser desorption/ionization time-of-flight mass spectrometry and thioacidolysis/liquid chromatography/electrospray ionization mass spectrometry. Anal Chim Acta 513(1):247-256. https://doi.org/10. 1016/j.aca.2003.11.085

19. Vázquez G, Fontenla E, Santos J, Freire M, González-Álvarez J, Antorrena G (2008) Antioxidant activity and phenolic content of chestnut (Castanea sativa) shell and eucalyptus (Eucalyptus globulus) bark extracts. Ind Crop Prod 28(3):279-285. https:// doi.org/10.1016/j.indcrop.2008.03.003

20. Laghi L, Parpinello GP, Rio DD, Calani L, Mattioli AU, Versari A (2010) Fingerprint of enological tannins by multiple techniques approach. Food Chem 121(3):783-788. https://doi.org/10.1016/j. foodchem.2010.01.002

21. Bernal JL, Del Nozal MJ, Toribio L, Del Alamo M (1996) HPLC analysis of carbohydrates in wines and instant coffees using anion exchange chromatography coupled to pulsed amperometric detection. J Agric Food Chem 44:507-511. https://doi.org/10.1021/ jf9406065

22. Cutzach I, Chatonnet P, Henry R, Dubourdieu D (1997) Identification of volatile compounds with a "toasty" aroma in heated oak used in barrelmaking. J Agr Food Chem 45(6):2217-2224. https:// doi.org/10.1021/jf960947d

23. Chatonnet P, Cutzach I, Pons M, Dubourdieu D (1999) Monitoring toasting intensity of barrels by chromatographic analysis of volatile compounds from toasted oak wood. J Agr Food Chem 47(10):4310-4318. https://doi.org/10.1021/jf981234t

24. Del Alamo M, Bernal JL, Nozal MJD, Gómez-Cordovés C (2000) Red wine aging in oak barrels: evolution of the monosaccharides content. Food Chem 71(2):189-193. https://doi.org/10.1016/ s0308-8146(00)00145-x

25. Vignault A, González-Centeno MR, Pascual O, Gombau J, Jourdes M, Moine V, Iturmendi N, Canals JM, Zamora F, Teissedre P-L (2018) Chemical characterization, antioxidant properties and oxygen consumption rate of 36 commercial oenological tannins in a model wine solution. Food Chem 268:210-219. https:// doi.org/10.1016/j.foodchem.2018.06.031

26. De Simón BF, Hernández T, Cadahía E, Dueñas M, Estrella I (2003) Phenolic compounds in a Spanish red wine aged in 
barrels made of Spanish, French and American oak wood. Eur Food Res Technol 216(2):150-156. https://doi.org/10.1007/ s00217-002-0637-4

27. OIV (2007). Compendium of International methods of analysis of wine and must. International Organisation of Vine and Wine

28. Corona O, De Filippi D, Scavone L, Plodari R, Riccobono P (2011) Vinificazione in bianco in presenza di chips di quercia di origine e livello di tostatura diversi. Ind Bev 40(235):24-34

29. Scalbert A, Monties B, Janin G (1989) Tannins in wood: comparison of different estimation methods. J Agric Food Chem 37(5):1324-1329. https://doi.org/10.1021/jf00089a026

30. Singleton VL, Orthofe R, Lamuela-Raventós RM (1999) Analysis of total phenols and other oxidation substrates and antioxidants by means of Folin-Ciocalteu reagent. Methods Enzymol 299:152178. https://doi.org/10.1016/S0076-6879(99)99017-1

31. Bate-Smith EC (1981) Astringent tannins of the leaves of geranium species. Phytochemistry 20:211-216. https://doi.org/10. 1016/0031-9422(81)85095-9

32. DiStefano R, Cravero MC, Gentilini N (1989) Metodi per lo studio dei polifenoli dei vini. L'Enotec (5, 25):81-89.

33. Bate-Smith EC (1972) Detection and determination of ellagitannins. Phytochemistry 11:1153-1156. https://doi.org/10.1016/ S0031-9422(00)88470-8

34. Corona O, Liguori L, Albanese D, Matteo MD, Cinquanta L, Russo P (2019) Quality and volatile compounds in red wine at different degrees of dealcoholization by membrane process. Eur Food Res Technol 245(11):2601-2611. https://doi.org/10.1007/ s00217-019-03376-Z

35. Corona $\mathrm{O}$ (2010) Wine-making with protection of must against oxidation in a warm, semi-arid terroir. S Afr J Enol Vitic 31(1):58-63. https://doi.org/10.21548/31-1-1401

36. Corona O, Scavone L, De Filippi D, Scrinzi C (2008) Influenza dei nutrienti azotati sull'attività di due ceppi di lievito nella vinificazione di uve bianche. L'Enol 44(12):87-97

37. Di Stefano R, Ciolfi C (1982) Produzione di acetaldeide da parte di stipiti di lieviti di specie diverse. Riv Vitic Enol 35:474-480

38. Singleton V, Timberlake C, Lea A (1978) The phenolic cinnamates of white grapes and wine. J Sci Food Agric 29:403-410. https://doi.org/10.1002/jsfa.2740290416

39. Roessler EB, Pangborn RM, Sidel JL, Stone H (1978) Expanded statistical tables for estimating significance in paired-preference, paired-difference, duo-trio test end triangle tests. J Food Sc 43:940-944

40. Sivonen H, Maunu SL, Sundholm F, Jämsä S, Viitaniemi P (2002) Magnetic resonance studies of thermally modified wood. Holzforschung 56(6):648-654. https://doi.org/10.1515/hf.2002.098

41. Čabalová I, Kačík F, Lagaňa R, Výbohová E, Bubeníková T, Čaňová I, Durkovič J (2017) Effect of thermal treatment on the chemical, physical, and mechanical properties of pedunculate oak (Quercus robur L.) wood. Bioresources 13(1):157-170. https:// doi.org/10.15376/biores.13.1.157-170

42. Coelho E, Teixeira JA, Domingues L, Tavares T, Oliveira JM (2019) Factors affecting extraction of adsorbed wine volatile compounds and wood extractives from used oak wood. Food Chem 295:156-164. https://doi.org/10.1016/j.foodchem.2019.05.093

43. Spillman PJ, Sefton MA, Gawel R (2008) The effect of oak wood source, location of seasoning and coopering on the composition of volatile compounds in oak-matured wines. Aust J Grape Wine Res 10(3):216-226. https://doi.org/10.1111/j.1755-0238.2004.tb000 25. $\mathrm{x}$

44. Chira K, Teissedre P (2014) Chemical and sensory evaluation of wine matured in oak barrel: effect of oak species involved and toasting process. Eur Food Res Technol 240(3):533-547. https:// doi.org/10.1007/s00217-014-2352-3

45. Zhang Z, Li D, Wang L, Ozkan N, Chen XD, Mao Z, Yang H (2007) Optimization of ethanol-water extraction of lignans from flaxseed. Sep Purif Technol 57(1):17-24. https://doi.org/10. 1016/j.seppur.2007.03.006

46. Garcia R, Soares B, Dias CB, Freitas AM, Cabrita MJ (2012) Phenolic and furanic compounds of Portuguese chestnut and French, American and Portuguese oak wood chips. Eur Food Res Technol 235(3):457-467. https://doi.org/10.1007/s00217-012-1771-2

47. Díaz-Maroto MC, Sánchez-Palomo E, Pérez-Coello MS (2004) Fast screening method for volatile compounds of oak wood used for aging wines by headspace SPME-GC-MS (SIM). J Agric Food Chem 52(23):6857-6861. https://doi.org/10.1021/jf049032m

48. Pollnitz AP, Jones GP, Sefton MA (1999) Determination of oak lactones in barrel-aged wines and in oak extracts by stable isotope dilution analysis. J Chromatogr A 857(1-2):239-246. https://doi. org/10.1016/s0021-9673(99)00785-2

49. Slaghenaufi D, Marchand-Marion S, Richard T, Waffo-Teguo P, Bisson J, Monti J-P, Merillon J-P, de Revel G (2013) Centrifugal partition chromatography applied to the isolation of oak wood aroma precursors. Food Chem 141(3):2238-2245. https://doi.org/ 10.1016/j.foodchem.2013.04.069

50. Nonier M, Gaulejac NV, Vivas N, Vitry C (2004) Characterization of carotenoids and their degradation products in oak wood. Incidence on the flavour of wood. C R Chim 7(6-7):689-698. https://doi.org/10.1016/j.crci.2004.03.010

51. Cinquanta L, Zarzana D, Planeta D, Liguori L, Albanese D, Di Matteo M, Corona O (2019) Use of potassium polyaspartate for the tartaric stabilization of sicilian white wines. Chem Eng Trans. https://doi.org/10.3303/CET1975047

52. Gerbaud V, Gabas N, Blouin J, Crachereau J (2010) Study of wine tartaric acid salt stabilization by addition of carboxymethylcellulose (CMC): Comparison with the protective colloids effect. OENO One 44(4):231. https://doi.org/10.20870/oeno-one.2010. 44.4.1474

53. Cheraiti N, Guezenec S, Salmon J (2009) Very early acetaldehyde production by industrial Saccharomyces cerevisiae strains: a new intrinsic character. App Microbiol Biot 86(2):693-700. https:// doi.org/10.1007/s00253-009-2337-5

54. Brejning J, Jespersen L (2002) Protein expression during lag phase and growth initiation in Saccharomyces cerevisiae. Int J Food Microb 75(1-2):27-38. https://doi.org/10.1016/s0168-1605(01) 00726-7

55. Bichescu C, Stanciu S (2019) The influence of oenological tannins on the fermentation and color stability of a Romanian red wine. Rom Biotech Lett 24(1):57-65. https://doi.org/10.25083/rbl/24.1/ 57.65

56. Oliveira CM, Ferreira AC, Freitas VD, Silva AM (2011) Oxidation mechanisms occurring in wines. Food Res Int 44(5):11151126. https://doi.org/10.1016/j.foodres.2011.03.050

57. Salgues M, Cheynier V, Gunata Z, Wylde R (1986) Oxidation of grape juice 2-S-glutathionyl caffeoyl tartaric acid by Botrytis cinerea Laccase and characterization of a new substance: 2,5-dis-glutathionyl caffeoyl tartaric acid. J Food Sci 51(5):1191-1194. https://doi.org/10.1111/j.1365-2621

58. Singleton VL, Cilliers JJ (1995) Phenolic browning: a perspective from grape and wine research. ACS Symposium Series Enzymatic Browning and Its Prevention. https://doi.org/10.1021/bk-19950600.ch003

59. Chen K, Escott C, Loira I, Fresno JD, Morata A, Tesfaye W, Calderon F, Benito S, Suárez-Lepe JA (2016) The effects of prefermentative addition of oenological tannins on wine components and sensorial qualities of red wine. Molecules 21(11):1445. https://doi.org/10.3390/molecules21111445

60. Barbosa C, Mendes-Faia A, Mendes-Ferreira A (2012) The nitrogen source impacts major volatile compounds released by Saccharomyces cerevisiae during alcoholic fermentation. Int J Food Microbiol 160(2):87-93. https://doi.org/10.1016/j.ijfoodmicro. 2012.10.003 
61. Molina AM, Guadalupe V, Varela C, Swiegers JH, Pretorius IS, Agosin E (2009) Differential synthesis of fermentative aroma compounds of two related commercial wine yeast strains. Food Chem 117(2):189-195. https://doi.org/10.1016/j.foodchem.200
Publisher's Note Springer Nature remains neutral with regard to jurisdictional claims in published maps and institutional affiliations. 